\title{
Des Moines Girl May Give Gibson His Type of '09
}

The Des Moines Capital, Des Moines, Tuesday November 17,1908

Gee, girls! how would you like to be the Gibson Girl of 1909? Some Des Moines girl may be taken as the type of the work of the great Charles Dana Gibson who spent a few hours in Des Moines Saturday and slipped unobtrusively out of the city after he had gazed long upon the well dressed throngs of Des Moines women who were out on dress parade. With him was Norman Hapgood, editor of Collier's Weekly. They were in search of "Types."

A new Gibson Girl is wanted by the famed Charles D. Gibson. He is tired of the languid, over-dressed, fashioned-designed femininity of the effete east. He wants life, color, happiness-a girl with a blush on the cheek and a girl with a smile in her eye. It is no longer to be the "Gibson pose." It is to be the Gibson face.

"Devilish pretty town, this Des Moines," said Charles D. Gibson, Esq., of New York City, as he got off the train at the Rock Island depot and started uptown to the business section of the city.

\section{Officer is Patriotic}

"You're gol durned right sir," said officer Joe Donahue as he swelled up with pride in his new blue uniform over the fact that he lived in Des Moines. He identified his interlocutor from pictures he had seen.

"Many pretty girls?" inquired the visiting artist.

Now, had it been any ordinary individual, officer Joe Donahue would have resented the question, for he is opposed to shipping the best of the home products out of the city.

"Right you are," said the officer, visibly puffing another notch. "Finest that ever set foot in the silk stocking or donned a fifty dollar piece of milliner's art. The best in the world, sir, the best in the world."

With that Gibson walked uptown; registered under the commonplace title of C. D. Gibson, and remained in Des Moines looking for "Types."

He walked through the department stores, viewed the girls 
behind the counters, gazing at a pompadour here, a marcel wave there, a pink cheek in this place and a ethereal one in another. From his selection which he retains from memory he will figure out that composite type which will mark the Charles Dana Gibson drawings of 1909.

\section{Finds Many Pretty Girls}

Before he left the city the artist declared he believed Des Moines had as many pretty girls as any city he has ever visited. "No particular type, you know," he explained. "Just a whole lot of fresh young, handsome girls whose thoughts are not centered about clothes and fashion entirely, but in whose eyes gleam the cordiality of good health."

The Gibson Girl with the marceled hair, the long kangaroo walk, the sickly-placid face is to be gone forever. In her place will be instituted the bright, fresh, visage of the western type. Not so tall, perhaps, but in the bloom of good health, no steel encompassed waists of 18-inch measurement; a girl with an eye that twinkles and cheek that carries with it the flush of health, happiness and right living.

Charles Dana Gibson and his noted companion left for Omaha where they are still searching for "types." There the same ideas will be carried out and the result will be a "Girl of the Central West."

She will have a Des Moines forehead, a St. Louis nose, an. Omaha head; but if it be entirely an Iowa girl it will be known that Charles Dana Gibson spotted his type on the streets of Des Moines and found his artistic ideal somewhere in the city.

\section{Born Same Cabin Different States}

Des Moines Daily News

Sunday August 2, 1908

The six Ayres children, one of whom now lives here, have a unique record. They were born in the same log cabin on the same farm, but in three different territories and one state.

On a farm two and one-half miles northeast of Ft. Madison, Iowa, Samuel A. Ayres was born in the then territory of Michigan in March, 1835; Gertrude Ayres Burch was born in the territory of Iowa, and Marion Oscar Ayres in the state of Iowa, all within ten years. 
Copyright of Annals of Iowa is the property of State of Iowa, by \& through the State Historical Society of Iowa and its content may not be copied or emailed to multiple sites or posted to a listserv without the copyright holder's express written permission. However, users may print, download, or email articles for individual use. 